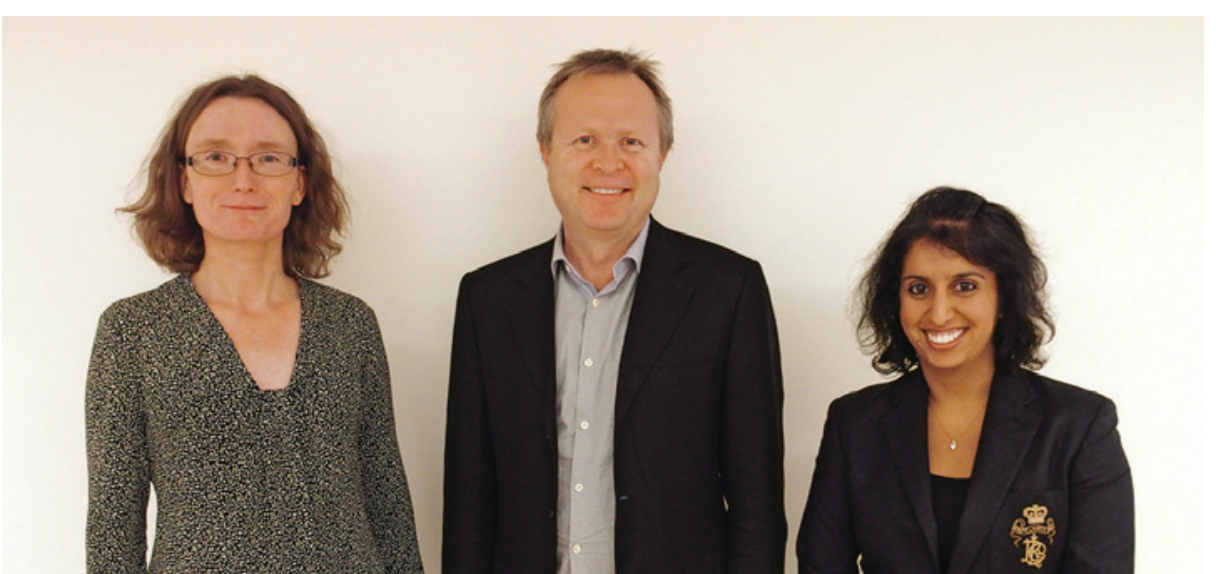

Artikkelens sisteforfatter professor Torbjørn Omland mellom artikkelens førsteforfattere, til venstre Siri Lagethon Heck og til høyre Geeta Gulati. Foto: André Øien

\title{
Kan hjerteskade ved brystkreftbehandling begrenses?
}

Brystkreft behandles oftest med cytostatika og strålebehandling som kan skade hjertet. Denne hjerteskaden ser ut til å kunne begrenses med forebyggende medikamentell behandling. Dette viser en ny norsk studie.

Moderne kreftbehandling har økt overlevelsen ved brystkreft, som er den vanligste formen for kreft blant kvinner. Adjuvant behandling består ofte av antrasyklinholdig cytostatika, taksaner og strålebehandling. Pasienter med en mer aggressiv HER2-positiv krefttype får også det monoklonale antistoffet trastuzumab. Både antrasykliner, strålebehandling og trastuzumab kan skade hjertet. En norsk studie som nylig er publisert i tidsskriftet European Heart Journal viser at denne hjerteskaden kan begrenses ved bruk av candesartan, som er en angiotensinreseptorblokker, og/eller metoprolol (1).

Studien omfattet 120 hjertefriske kvinner med tidlig brystkreft som skulle ha adjuvant behandling med lave eller moderate doser antrasykliner. Pasientene ble randomisert til candesartan og metoprolol, candesartan og placebo, metoprolol og placebo eller bare placebo. Pasientene ble undersøkt med MR av hjertet, ekkokardiografi og blodprøver før og etter antrasyklinbehandling. Pasienter som fikk strålebehandling eller trastuzumab, ble også undersøkt etter at behandlingen var avsluttet. Resultatene viser at den adjuvante behandlingen av relativt friske kvinner kun ga et lite fall i systolisk hjertefunksjon, målt ved MR, og at dette fallet ble forebygget av bruk av candesartan. Det var ingen forskjell i fall i ejeksjonsfraksjon mellom pasienter som fikk eller ikke fikk metoprolol.

- Dette er den største studien om forebygging av hjerteskade ved adjuvant behandling av tidlig brystkreft der MR av hjertet brukes til å måle hjertefunksjonen, sier Siri Lagethon Heck, som er radiolog og ph.d.-kandidat ved Akershus universitets- sykehus. - Artikkelen omfatter ikke oppfølgingsdata utover den adjuvante brystkreftbehandlingsperioden, men forskningsgruppen er i gang med en oppfølgingsstudie, forteller Heck, som ser frem til å se hvordan hjertefunksjonen påvirkes over tid, og hvorvidt den beskyttende effekten av candesartan holder seg utover behandlingsperioden.

- Større studier, hvor man også ser på pasienter med flere risikofaktorer, bl.a. tidligere hjertesykdom, og langtidsobservasjoner må til for å avgjøre om candesartan har en plass i forebygging av hjerteskade under behandling av brystkreft, sier Heck.

\section{Samarbeid på tvers av avdelinger og sykehus}

Rekruttering og oppfølging av pasientene forgikk ved Akershus universitetssykehus. Førsteforfatterne Geeta Gulati og Siri Lagethon Heck er begge ph.d.-kandidater i forskningsgruppen som er ledet av Torbjørn Omland, sisteforfatter av artikkelen. Studien er et samarbeid mellom flere avdelinger ved Akershus universitetssykehus og Oslo universitetssykehus. Dessuten har Jeanette Schulz-Menger og Florian von Knobelsdorff-Brenkenhoff ved Charité Universitätsmedizin i Berlin deltatt i prosjektet.

\section{Kaveh Rashidi}

Tidsskriftet

\section{Litteratur}

1. Gulati G, Heck SL, Ree AH et al. Prevention of cardiac dysfunction during adjuvant breast cancer therapy (PRADA): a $2 \times 2$ factorial, randomized, placebo-controlled, double-blind clinical trial of candesartan and metoprolol. Eur Heart J 2016; e-publisert 21.2.2016.
Ordforklaringer

HER2-positiv: HER2 er et protein som fungerer som mottaker for epidermal vekstfaktor. Genet for HER2 er oppregulert hos ca. $30 \%$ av brystkreftsvulster og gir hissig celletilvekst.

Monoklonalt antistoff: Et antistoff som produseres fra en enkelt B-celle.

Ejeksjonsfraksjon: Prosentdelen av hjertekammerets fyllingsvolum som pumpes ut i et hjerteslag.

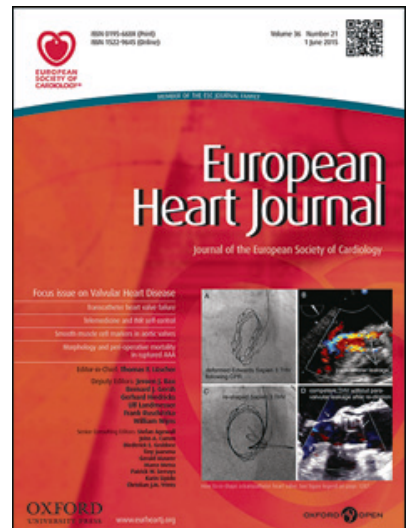

Artikkelen ble publisert i European Heart Journal i februar 2016 